Relations industrielles

Industrial Relations

\title{
Wildcat Strike in Lake City, by Maxwell Flood, Study no 15, Task Force on Labour Relations, Ottawa, Privy Council Office, 1968, 146 pp.
}

\section{F. R. Anton}

Volume 26, numéro 1, 1971

URI : https://id.erudit.org/iderudit/028203ar

DOI : https://doi.org/10.7202/028203ar

Aller au sommaire du numéro

Éditeur(s)

Département des relations industrielles de l'Université Laval

ISSN

0034-379X (imprimé)

1703-8138 (numérique)

Découvrir la revue

Citer ce compte rendu

Anton, F. R. (1971). Compte rendu de [Wildcat Strike in Lake City, by Maxwell

Flood, Study no 15, Task Force on Labour Relations, Ottawa, Privy Council

Office, 1968, 146 pp.] Relations industrielles / Industrial Relations, 26(1),

249-251. https://doi.org/10.7202/028203ar

Tous droits réservés @ Département des relations industrielles de l'Université Laval, 1971
Ce document est protégé par la loi sur le droit d'auteur. L’utilisation des services d’Érudit (y compris la reproduction) est assujettie à sa politique d'utilisation que vous pouvez consulter en ligne.

https://apropos.erudit.org/fr/usagers/politique-dutilisation/ 
Wildcat Strike in Lake City, by Maxwell Flood, Study no 15, Task Force on Labour Relations, Ottawa, Privy council office, 1968, $146 \mathrm{pp}$.

It may not be fair to a sociologist to have an economist review his research. In reading this interesting publication I was constantly searching for the $\ll \mathrm{em}$ pirical $\gg$ evidence on which some conclusions were based. But given the precipitate nature of wildcat strikes and their relatively short duration, it is probably difficult to undertake an $\alpha$ in depth» study of the underlying causes of industrial conflicts of this kind.

The chronology of events associated with the strike is briefly as follows. Renegotiation of the collective agreement began about two months prior to its expiry date. After a dozen sessions (spread over $3 \frac{1}{2}$ weeks) negotiations broke down. The union asked for mediation but the company refused; the union then applied for the assistance of a Conciliation Board. While the Board was being established the company offered a settlement. The union negotiators rejected this offer and reported the action they had taken, both verbally and by leaflet, to the executive and membership. Subsequently the union informed its members that a conciliation chairman had been appointed but that negotiations with the company would continue pending a meeting with the Board.

Four days after the agreement expired the union negotiating committee met with union stewards to report the outcome of conciliation and to say that they had agreed with management to either settle within four days or to announce a deadlock in bargaining which would clear the way to call a legal strike. While this meeting was taking place a group of about 20 workers, coming off the afternoon shift, began to picket part of the plant; they were joined by others from the same shift. Workers on the incoming night shift observed the picket lines. A wildcat strike had started. During the night picketers closed several subsidiary plants and despite exhortations to return to work by union stewards, and subsequently by the union's president and executive, the picket lines were observed.

The strike lasted about four days. During this interval union officers used leaflets and the radio in an attempt to induce employees to return to work; special meetings were also held with dissident leaders. Finally, a general meeting was held to give a progress report on the state of negotiations. A vote was taken at this meeting in favour of calling off the strike. Work resumed next day but at the same time management dismissed thirty-five workers for violence and sabotage on the picket line, and sixteen were suspended indefinitely.

Two weeks later union negotiators and management reached a settlement but this was rejected by a small majority of those members who voted. Shortly thereafter the union distributed a leaflet announcing that they had won an additional 3 cents per hour on the first year of the agreement and indicating that rejection of this final offer would simultaneously give the union authority to call a strike. The offer was accepted by almost two-thirds of the voting members.

The theory and frame of reference used by the author to analyse this wildcat strike is based on Smelser's theory of collective behaviour ${ }^{1}$. The theory implies that a strike of this kind represents « collective behaviour 》 belonging to the « hostile outburst» category. Within this framework, the author seeks to identify the elements of structural strain which may, in part, explain the occurance of the outburst. Strain is identified as emanating from four possible sources: (1) historical ; (2) the structure of the union; (3) the structure of the company and (4) external influences.

The evidence presented supports the assertion that some strain existed among union members because of dissatisfaction with the terms of the previous collective agreement and the way it was negotiated. In the interim, it appears that two dissident groups had emerged within the plant. One group felt that the union needed more autonomy and that the local was too much influenced by the regional and international officers. This group set out to discredit their local officers as well as the existing union structure. The other was a left wing group which campaigned for the adop-

1 Neil J. Smelser, Theory of Collective Behaviour, New York, The Free Press of Glencoe, 1963. 
tion of a much more militant approach to collective bargaining. The significance of these factions within the union (which had a membership in excess of 10,000 ) is documented and it appears that the \& collective 》 discontent of these two groups was strong enough to bring about a wildcat strike.

The author suggests that one of the main causes of the build-up of strain was because of the relatively large size of the local which led to inadequate communications between union officers and the membership. Factions were permitted to develop in various parts of the plant which could discredit the incumbent officers and plot for their overthrow. How deep the dissatisfaction was with the terms of the previous contract and the manner in which agreement was obtained is not dealt with in detail but it is alleged that the president of the local (aided and abetted by his regional and national officers) was more concerned about obtaining a settlement than considering the demands of the membership. The dissatisfaction stemming from this earlier agreement may have been aggrevated by the relatively secretive approach the union used in their negotiations with management. And while secrecy may be essential at certain stages in negotiations, good communications are equally necessary. If workers feel that their grievances are legitimate they are unlikely to accept the argument that secrecy is diserable at specific times.

The writer asserts that a second communication failure on the part of the union was associated with the structural strains emanating from the company's activities in the area of technological change and management's strategy in the handling of resulting grievances. $\mathrm{He}$ further states that the ongoing "process of rapid technological change produced a large volume of grievances that could not be adequately handled by the union» and that «this problem was exacerbated by the company's retreat into a legalistic posture with respect to grievances 》. One may take issue with the writer over these assertions. There is no supporting evidence to show (a) that grievances were on the increase (b) what proportion of these grievances were caused by issues involving technological change and (c) that technological change produced such a large volume of grievances that they could not be handled by the union. Given the steady rising demand for the products of this industry and the increased demand for labour to produce these, it is questionable if many grievances would stem from technological change. Moreover, my guess is that management's adoption of a «legalistic posture 》 in resolving grievances makes sense in light of arbitration procedures in Ontario of elsewhere in Canada. There is very little in this study to suggest that the relations betwen management and ernployees were poor but it came as a shock to learn that management could be so inept to test the picketers' mettle by attempting to force a train through the picket line.

\section{Eruption of Wildcat Strikes}

The author argues that the eruption of a wildcat strike is usually associated with a precipitating incident in response to which a small group of workers initiate the wildcat. He rightly asserts that this precipitating incident is often wrongly labelled as the cause. Wildcat strikes can seldom be explained in terms of the particular incident associated with their eruption and in this case study it is hard to imagine that a small group of dissidents could start picketing the plant between 9 p.m. -10 p.m. and have their picket lines immediately respected had there not been a prior build-up of disaffection before the event. Some tenuous evidence of (isolated) provocative actions suggests a smouldering discontent among the rank and file. For instance, the circulation of a leaflet asking workers to stage a wildcat, and a work slowdown in one department, when coupled with the feeling that senior officers of the union were alienated from the membership might suffice to cause the eruption. This particular wildcat was not a bitter strike; it was more a demonstration suggesting that the strains (past and present) were building up against the union. But in the field of labour-management relations as in many other potential conflict situations an outburst such as the one described in this case study serves as a useful safety valve. Failure on the part of union leaders or management to recognize strain among workers can lead to a swift deterioration in unionmanagement - employee relations. The important questions are how to spot 
such tensions in time and what action to take to prevent an eruption? The behavioral sciences cry out for more research to be done in these vital areas. In this dispute (a part from the train incident mentioned above) once faced with the fait accompli both the company's and union's executive appeared to show good sense and act in good faith. Parenthetically, shortly after a settlement was reached the president of the local and several of his executives were dismissed from office.

\section{F. R. ANTON}

\section{A Study of the effects of the $\mathbf{\$ 1 . 2 5}$} minimum wage under the Canada labour (Standards) Code, by Mahmood A. Zaidi, Study no. 16, Task Force on labour relations, Ottawa, Privy council office, 1970, $163 \mathrm{pp}$.

Cette étude no 16 de l'Equipe spécialisée en relations de travail nous permet notamment de faire un tour d'horizon des salaires minimum tant du Canada et des provinces canadiennes que des Etats-Unis et de certains états.

L'auteur s'est inspiré d'un nombre considérable de travaux publiés sur ce sujet (les listes de références sont longues) et nous fait part du résultat de ses recherches parfois élaborées.

Depuis 1917, lorsque fut votée la première loi du salaire minimum au Canada, en Alberta, que de chemin parcouru, mais où en sont encore ces lois ? C'est là une autre question qui déborde le cadre de l'étude qui avait été proposée à M. Zaidi.

On établit, en général, un salaire minimum, comme le fait remarquer l'auteur, quand on croit que les mécanismes du marché ont mal fonctionné. «Ce mauvais fonctionnement peut revêtir deux formes qui peuvent être ou ne pas être redressées. Dans le premier cas, l'offre et la demande ne jouent pas de manière à donner un «salaire minimum vital » à ceux qui fournissent la maind'oeuvre... Dans le second cas, l'employeur peut, dans un but précis ou non, exploiter délibérément le travailleur en le payant moins que ce à quoi il a droit 》.

Puisque en somme le nombre de salariés touchés par la loi fédérale du salaire minimum est peu élevé, l'impact de la hausse du taux à $\$ 1.25$ n'eut pas d'effets remarquables sur l'économie. M. Zaidi fait cependant remarquer à juste titre, que cette hausse entraîna une controverse.

L'analyse de la situation dans les villes à salaire élevé et dans celles à bas salaire, a démontré, selon l'auteur, qu'il existait de grandes différences dans l'impact du salaire minimum. Les villes à bas salaire enregistrent une diminution des emplois et les villes à salaire élevé ont au contraire des gains appréciables.

Un autre avantage du salaire minimum est à l'effet de réduire les différences de salaire entre hommes et femmes.

Les conclusions de M. Zaidi (traduites en français, en appendice) sont les suivantes: "Bref, bien que les salaires minimum n'aient apparemment pas provoqué un accroissement du chômage dans l'ensemble de l'économie, ils l'ont néanmoins engendré dans une certaine mesure dans les industries qui relèvent du gouvernement fédéral et dans les provinces. Ces lois ont également eu pour effet de réduire les différences entre les travailleurs des deux sexes, entre les employés de bureau et les travailleurs manuels, et les différences géographiques de salaires. Dans la plupart des cas, les sociétés se sont très bien soumises à la loi, et le facteur coût n'a pas semblé avoir beaucoup de conséquences 》.

\section{Jacques LAFRENIERE}

Les deux sexes dans la fonction publique, par Kathleen Archibald, Rapport à la Commission de la fonction publique du Canada, Ottawa, Imprimeur de la Reine, 1969, 246 pp.

Le rapport présenté établi par Kathleen Archibald et qui a été présenté à la Commission de la Fonction publique au Canada, constitue une étude très approfondie sur la situation passée et actuelle des deux sexes dans la Fonction Publique.

Il a été établi, nous dit son auteur, principalement à partir de données statistiques déjà publiées et faites pour le 